\title{
Teaching Academic Writing for the Disciplines: How Far can We Be Specific in an EAP Writing Course?
}

\author{
Boitumelo Tiny Ramoroka \\ University of Botswana \\ Center for Academic Development \\ Communication and Study skills Unit \\ Private Bag 0022 Gaborone, Botswana
}

Fax: 267-390-2884

Tel: 267-355-2997/7508-9255

E-mail: ramorokab@mopipi.ub.bw

Received: May 29, 2012

Accepted: June 28, 2012

Published: August 21, 2012

doi:10.5430/elr.v1n2p33

URL: http://dx.doi.org/10.5430/elr.v1n2p33

\begin{abstract}
In recent years research on writing in academic contexts began to focus on the types and nature of writing tasks students encounter in the content subjects. The pedagogical motivation for researchers has been to better understand students' writing needs in their content subjects in order to prepare them for academic writing in their disciplines. Much of this research has focused on fields of study like science and engineering (Braine 1989, 1995,) business courses (Zhu 2004) and nursing and midwifery (Gimenez 2008). I have found nothing that relates specifically to academic writing for Media Studies. Using semi-structured interviews with staff and students, and an analysis of students' written assignments, this study does research on students' writing tasks in two writing contexts, the EAP preparatory course and Media Studies at the University of Botswana. The aims of the study were to find out whether there are similarities in the tasks and genres that students write in the EAP course and in the content course, to what extent the essays done in the EAP writing course give support for disciplinary writing and to find out what tutors perceive to be good writing. The results reveal that there are variations in writing tasks and differences in emphasis in the two writing contexts. These variations can be problematic for the EAP tutors who have to prepare students for writing in the disciplines.
\end{abstract}

Keywords: Academic writing, Writing in content courses, Disciplinary writing, Skills transfer

\section{Introduction: The situated nature of academic writing}

Academic writing at university level is a challenging and often the most demanding task for a lot of students. When students enter the university, they are expected to adapt to new ways of writing, that is, new ways of interpreting and organizing knowledge, writing conventions and expectations that are different from the kind of writing they did at secondary schools and that are specific to their disciplines. Ability to write well is important for success in most disciplines. Academic writing, especially essay writing becomes central to achieving academic success and is often the major form of assessment in many courses. Hence academic writing comes to be an essential skill that students need to master in order to be successful in their studies.

Students' writing at the university is largely situated in their disciplinary programmes and students are confronted with various academic practices of writing in different disciplines. However the teaching of writing skills seems to occur mainly in the English for Academic Purposes (EAP) class. The assumption behind the EAP writing course is that what students are taught there will help them improve their writing in the disciplines. There is often the assumption that there are "homogenous set of requirements" (Gimenez 2008:52) which are common across disciplines and that students can acquire these in their writing class.

Research (Leki and Carson 1997, Gimenez 2008) has shown that assumptions about homogeneity of writing requirements do not always work and that there is often a disjunction between the way students are taught academic writing skills in the EAP course and the expectations of tutors in the disciplines. Research has also noted that the writing class differs from other academic courses in the emphasis placed on various aspects of academic writing. For instance, essay writing which is taught in the EAP class is often approached in a generic way and in most cases EAP tutors seem not to take into consideration the context and practices in which academic writing takes place, which is 
in content courses. This approach to teaching the essays ignores the fact that academic writing varies across academic disciplines and that "such variation embodies different social relationships between the reader and the writer as well as different values and beliefs underlying discourse practices in various discourse communities" (Zhu 2004:30a).

Ignoring the socio-cultural context and practices of the disciplines in which writing is situated can compound the problems of ESL students as they learn to write in their disciplines. So when students have difficulties in writing they are seen as students' own weaknesses. However, much research has shown that "students entering academic disciplines need specialized literacy that consists of the ability to use discipline-specific rhetorical and linguistic conventions to serve their purpose as writers" (Berkenkotter et al 1991:19).

\section{Disciplinary differences in academic writing}

The literature on writing in academic contexts has shown that there is growing interest in examining writing in specific disciplinary courses and examining the socio-cultural context in which real writing takes place in order to understand the expectations and goals of academic writing in these courses. This is based on the premise that to teach academic writing successfully, EAP tutors must be aware of what is happening in the content departments (Braine 1989).

Research into academic writing has tended to confirm the existence of disciplinary variations in the nature and types of writing tasks assigned to students. For instance, a recent study by Nesi and Gardner (2006) at the University of Warwick looked at genres or writing tasks students are expected to produce in specific departments. This study looked across four broad disciplinary groupings and twenty subject areas, and the results of the research provided useful insights and a better understanding of the types of assignments that are done in different disciplines. Their study was also enriched by interviews with tutors in the departments that were involved in the study. Although the traditional assignment types like the essay, book review, laboratory report and dissertation were the core of most disciplines, there were also specific professional genres that were linked to applied disciplines like Law, Medicine and Engineering. The laboratory report was the core assignment in the sciences while the essay was common in the humanities. They explain professional genres as genres that position students as professionals, or where students simulate professional writing. In such genres, for instance, in the medical school students are given assignments like a case study report which assess their competence as they work towards becoming medical practitioners. Law students write case notes which simulate 'common forms of legal writing' (Nesi and Gardner 2006:9) and so forth. They also noted that assignment types differed in rhetorical structure, audience and purpose across and within disciplines.

Similarly Zhu (2004b) examined writing and genres that students are required to produce in the business faculty. Zhu carried out a comprehensive survey of writing in a business course at a large university in the Southeast of the United States. Zhu analyzed 95 course syllabi, handouts on writing assignments form undergraduate and graduate courses. He analyzed 242 assignments from both undergraduate and graduate courses and students' writing samples with tutor feedback. The data sources included interviews with faculty members. Zhu found that writing assignments in this faculty were diverse in terms of genre types. Some assignments represented academic genres (which are common across academic disciplines) such as the research paper, the article or book review. He also found out that there were also genres that were specific to the business discipline such as case analysis, business reports, business proposal, business letters and design reports. He noted that the business genres required problem solving, decision making and persuasion skills and that they were meant to socialize students into the business world. The assignments required students to assume the social roles like business professionals.

The findings of this study suggest a discrepancy between skills taught in the EAP writing course and the skills required in business courses. For instance, students in the business courses write for a wide range of audiences, both academic and professional. Students in business are also held responsible for the content of their writing. A similar observation was made by Leki and Carson (1997). Hyland (2008b, 2005a) also noted that there are differences in what is valued across disciplines. For example, the humanities and social sciences value analyzing and synthesizing information from many sources while in the sciences and technology courses "activity based skills like describing procedures, defining objects, planning solutions are required" (Hyland 2008:550b).

Variations exist also within written texts that are given the same label. For instance, some studies showed that although disciplinary labels are a good source of insight, they are not necessarily helpful, as Swales' definition of genre may suggest (Swales 1990). Reliance on genre labels has been problematized by Samraj (2004; Hyland 2008b). Samraj for instance showed that variations begin to show when we look at written texts that are given the same label. Samraj explored the nature of the research paper in graduate courses in two related fields in an L1 context. The 
research papers were from a Master's in Science (MSc.) program and were from Wildlife Behavior, Conservation Biology and Resource Policy courses. The research papers were analyzed and compared for the overall organization, the claims that students made to assume certain roles and for the use of intertextual links. The study highlighted differences in research papers across the two disciplines. For instance, there were slight differences in task requirements and differences in organizational patterns among the three courses. The Conservation Biology papers tended to have a problem solution organization. The Wildlife Behavior papers did not have a recognizable problem solution organization, but were organized by themes or chronologically. Overall the study revealed textual variations in written texts that were given the same label.

The variations presented above present a lot of difficulty for students, particularly those who have to operate within different disciplines or who are doing interdisciplinary course (Hyland 2002d). This poses a challenge for the EAP teacher who has to find common ground about what to teach.

It is against this backdrop that this study seeks to explore academic writing in the EAP writing course and in a content course (Media Studies) at the University of Botswana. The study attempts to answer the following research questions:

i) What writing tasks are students assigned in the EAP preparatory course and in the Department of Media Studies.

ii) To what extent does the EAP writing course constitute effective support for disciplinary essay writing?

iii) What tutors consider to be good academic writing?

The study is useful for a number of reasons. Firstly, research into EAP writing and discipline specific writing is crucial to the understanding of writing in the disciplines. Baynham (2000:17) suggests that "in order to understand the problematic (sic) of the novice writer, we need to understand the disciplinary contexts within which they are required to write..." The study will help to unpack the writing requirements of students in the two disciplines in this study. This is important because we need to commit our EAP pedagogic practices to instruction that is informed by research into the disciplines that students are writing themselves into. This is the rationale for this study.

In this paper I recognize that "learning an academic discourse is not a simple matter of learning a skill, but it is bound up with particular beliefs, values and identities" (North 2005:530), and these are embedded in the different disciplines. My paper will suggest a move from the generic, skill based practice in the EAP writing courses, to learn more of what is happening in the disciplines and what sorts of writing tasks students are assigned in their disciplines.

\section{The Study}

\subsection{The context of the study}

The study reported here was part of a broader study that examined several aspects of ESL writing in content courses. The study was undertaken in two departments at the University of Botswana, the Department of Media Studies which is in the Faculty of Humanities and the Department of Communication and Study Skills. The Department of Communication and Study Skills offers EAP writing to all first year and new students at the University of Botswana. The course being offered is a General Education Course (GEC) and students are required to do GEC 111 and GEC 112 in their first year. The Department of Media Studies offers the Bachelor in Media Studies Degree (BMS). The program introduces students to the world of electronic and print journalism. It opens career opportunities in journalism, both print and electronic as well as script writing, advertising and public relations.

\subsection{Data collection and analysis}

This paper reports on a total of 27 interviews with tutors and students in these departments. I interviewed 11 lecturers from the Department of Communication and Study Skills and 7 lecturers from the Department of Media studies. A total of 9 students who were in their $3^{\text {rd }}$ and fourth year of Media Studies volunteered to participate in the study.The interviews were meant to discover the participants' views on the types of assignments students are required to write in the two departments.

The interviews were carried out individually and each interview was about 30 minutes long. These were recorded and later transcribed for analysis.Sampling of participants for the study was carried out and it was focused at finding the right tutors and students for the study, which were people with the experience relevant for the study. The sampling was purposive. Dornyei (2007:126) explains that the “ $\ldots$ the main goal of [purposive] sampling is to find individuals who can provide rich and varied insights into the phenomenon under investigation so as to maximize what we can learn". The research instruments used for both tutors and students was the semi structured in-depth 
interview guide (see appendix A) which provided me with guidance and direction for asking questions. It provided some flexibility for the interviewees to elaborate on any issues in an exploratory manner.

Besides the interviews, I also collected 75 samples of written assignments from students ( 25 from Media Studies and 50 from the EAP writing class). The EAP assignment was a major assignment that students did after being introduced to academic writing at the university. Media studies samples were take- home assignments.

To answer the research questions I analyzed the data in several ways. To answer the first question involved the interview transcripts. The interviews were transcribed verbatim and using Nvivo software they were analyzed for emerging themes. In the process of interviewing I was particularly attentive to responses that outlined the types of writing tasks that students are assigned in the two departments. Therefore in analyzing the interview data I identified units of analysis where participants discussed the types of writing tasks assigned to students and the nature of prompts the students are given. Research questions two and three also involved interviews.

Another way I analyzed the data to answer the first research question involved doing a content analysis of the actual written assignments and writing samples.Similar to Zhu, (2004b), I looked at the overall purpose of each assignment and the specific tasks demanded by the assignment orwhat the prompts required the students to do. I also identified the writing tasks by using thelabels assigned to the different tasks as expressed by the participants in the interviews. Where I was not clear on the demand of the task, I consulted one of the Media Studies lecturers interviewed to get insider perspective on the assignment and what it required the students to do. This helped me to identify the types of writing tasks and the genres students are assigned in the two departments.

\section{Findings}

In what follows, I will review the types of assessed written assignments I found out from both the interviews and the samples of written assignments I collected. I will report on the views of the tutors and students of the EAP writing course and the extent to which it constitutes support for writing in their disciplines. I will also report on tutors consider to be good writing. The participants discussed a variety of issues during the interview and because of the scope of the paper I cannot report everything they reported.

4.1 Research question 1: What writing tasks are students assigned in the EAP preparatory Course and in the Department of Media Studies.

4.1.1 The traditional essay: The 'default genre' in both EAP and Media Studies.

Both EAP and Media Studies departments emphasized the importance of essay writing. It emerged from the interviews that students at the university write mostly essays, particularly in the first two years of university learning. The traditional essay writing was seen particularly as an important skill to master by the content tutors in Media Studies department as it plays a decisive role in the overall assessment of students.

The essay length for Media Studies essays varies in length and would usually be between 1200 and 1500 words. This assignment type entails doing research on a particular topic that students would have covered in their course and synthesizing information from different sources to write the essay. Students are usually asked to consult at least five different sources. Below is a typical example of an essay assignment topic from one of the Media Studies courses, (BMS BMS 302- Gender, Sex and Ethnicity in Media)

i. Do media images and messages only reflect the world, or do they also create it? Clearly they do both. But many studies demonstrate that media messages do not reflect the world as it really is. There are far more people of color, disabled people, non-heterosexuals, seniors an poor people in the real world than we see on TV or in the movies. Media portrayal of women often leaves much to be desired, especially women in advertising. Discuss with reference to both print and broadcast media.

EAP tutors reported that students learn and write the traditional essay because students engage in this type of genre at the university in most courses they do. Their view of the EAP writing course is to equip students with the skills they require to be successful in writing in their disciplines. However their responses to questions on the types of prompts they give to students were quite varied and reflected the tutors' differences in emphasis and approach to teaching essay writing. For instance, most tutors indicated that the types of essay prompts they give to students are on general topics "in the sense that they would not disadvantage the students irrespective of what discipline they come from". The tutors indicated that the topics that the students are given can be on a wide range of themes like current or topical issues like capital punishment, issues of democracy, tourism, criminal justice and social problems like HIV/AIDS. Students can write on personal topics like 'my first day at the university' or on their experiences like 
'how to retrieve books from the library'. The writing tasks that students are given range from descriptive, narrative, argumentative and expository writing and are usually short essays of about 500-700 words in length.

The essay prompts that tutors give to students seem to point to tutor beliefs that there are general skills that students could learn in the EAP course which could be transferred to their disciplines. Therefore the topics that they give students are used as a springboard for practising these writing skills. These kinds of essay prompts do not require students to write from sources. This is also reflected in tutors' responses about what they emphasise when teaching students essay writing. The responses that came out repeatedly were that the tutors put more emphasis on how students are able to express themselves, on language rather than content. One tutor pointed out that "the content was a means to an end". So students are not held responsible for the content of their writing as seen by Leki and Carson (1997).

There was, however, some commonality across the two courses in that essay prompts given to students were mainly persuasive in nature and required students to argue and present their position. In this kind of writing the students audience is the lecturer who gives the marks. Below are examples of such assignments from Media Studies courses and the EAP course.

i. "Gender based restrictions on media representations in Africa constitute a form of neo-colonialism which are contrary to African cultural traditions". Explain, with evidence, whether you agree or disagree with this quotation. (BMS 302- Gender, Sex and Ethnicity in Media)

ii. "'Othering' is a natural human instinct. It only becomes dangerous when it is used for the purpose of social exclusion". Debate this quotation by applying it to specific examples of Batswana imaging non Batswana.(BMS 401-Imaging Africa.)

iii. The small population of Botswana has got both advantages and disadvantages. Discuss. (EAP)

1v. Our lives would be better without media. Do you agree or disagree. (EAP)

Furthermore both Media studies and EAP tutors' echoed the same views about what is expected in essay writing. The expectations were that students should display the following skills:

- Synthesis of ideas from multiple sources and showing understanding of what has been read

- $\quad$ supporting claims with evidence

- Originality and creativity

- Taking a position and being heard

- Being critical

- A thorough discussion of concepts.

- Clarity of argument

- Showing awareness of both sides of an issue

4.1.2 Variations within the traditional essay type

The study of writing in Media Studies indicated that writing served different purposes and required students to assume different roles depending on the communicative goals of the course they are doing. Survey of students writing tasks noted variations within the same genre label of the essay. For instance, essays prompts were varied and elicited different outcomes from students. The essays engaged students in a variety of rhetorical modes such as

- a critical analysis /evaluation of media content,

- a critique of films

- application of theories and concepts to a particular context,

- discussion and exploration of a concept

- $\quad$ argumentative writing.

This finding is generally congruent with Nesi and Gardner's findings that "students may be required to apply different sets of rhetorical conventions to meet the demands of different course modules" (2006:2) even within the discipline and there is "need for students to be alert to differences not only across subject areas, but also across assignments" (page 114). Stierer (2000) also found out that students in the MA in Education programme at Open University were expected to produce a broad range of different types of writing or genres. This may be problematic 
for the teaching of essay writing in the EAP course where students come from different disciplines and the EAP tutors have to find common ground on what to teach.

\subsubsection{Assessed written genres specific to Media Studies}

While the researched essay was common to both departments, there were other genres that were more 'profession' specific that students were required to write. For instance, Media Studies students do both theory and practical courses and some courses are a combination of both. In some Media Studies courses which are named "professional" in the context of university writing, students could be required to write the following genres where they position themselves as professional writers

- Critical reviews of published materials like newspaper articles brochures and magazines. Comments from the tutors indicated that being 'critical' was considered essential skill in Media studies.

"I expect them to do is I want them to look at issues and the way media reported them because I teach concepts about how to be very critical in terms of how the media reported an issue". (Media Studies)

"I tell them pick an issue, evaluate and critically analyse how the media reported that issue" (Media Studies)

- Documentary writing- this will involve doing research like interviewing relevant people e.g. eye witnesses to provide factual information to write the documentary

- animated projects

- script writing (for radio or TV)

- proposals for newspaper production or TV production

- production of adverts. The importance of persuasion in advertising was emphasized by one participant

I teach persuasion in the context of campaigns, I don't teach persuasion in the context of essay writing... of course it's going to show up in the writing, for example if you produce an advert, the intention is to persuade people to buy the product or to do maybe like in public communication campaign, the social marketing campaigns maybe to persuade people to adopt safe sexual practices so I teach persuasion in that regard, do you understand, not in terms of writing an argumentative essay, so I don't teach it in that way, I teach it in the context of campaigns".

- Creative writing- students come up with an imaginary situation and a story line. The writing here is highly descriptive and students are expected to use words to describe or paint a vivid picture of their characters, their facial expressions, their mood etc.

- $\quad$ articles for a newspaper

- critiquing films and reviewing documentaries

These genres reflect the conventions and purposes of workplace written genres. Here students are required to simulate the professional writing tasks that are done in the workplace and they are assessed on that. One of the findings of this research is that when students reach $3^{\text {rd }}$ and $4^{\text {th }}$ year level of undergraduate courses their writing becomes "specifically tied to their disciplines" (Zhu 2004:30a) because that is when they begin to pursue their specialization.

4.2 Research question 2: To what extent does the EAP writing course constitute effective support for disciplinary essay writing?

4.2.1 Views on whether the EAP course constitutes effective help for disciplinary writing.

Students' comments on whether the EAP writing course constituted effective help for writing in the content courses indicated that they were generally satisfied that they had learned skills that were useful in their content courses. For example, one student commented that the writing course gave him a 'good start for most of (my) assignments and (my) writing'. Students indicated that the course offered them the only support for writing in their content courses and often their content lecturers refer them to EAP tutors when they have writing problems. One student pointed out that "in some subjects the lecturers do not show us how the assignment has to be written so we have to use the knowledge from CSS"

When probed further on which aspects of the EAP preparation was most helpful in their discipline writing tasks students outlined how to manage or use and cite sources in writing as one aspect of writing they found helpful. The other aspect that students discussed included organisation of ideas and structuring of the essay. Students discussed 
topics like 'knowing how to structure an essay with a good introduction', 'knowing how to tie the introduction to the conclusion', 'developing the topic sentence', 'how to present ideas in a coherent manner' and 'developing good paragraphs' as some of the skills that they learnt from the course. The comments that students made seem to suggest some evidence of skills transfer from the EAP course to their content courses. Students seem to draw from their experiences and knowledge gained from writing in the EAP course when they write essays in their disciplines. The students' comments also seem to suggest that the EAP writing course seems to be the only source of support available for students.

It is interesting to note that although some students emphasised that the writing course helped them a lot, some pointed out that the course did not link with what they were doing in the content course in terms of subject matter. They felt that this was a limiting factor for them because they could not apply much of the content from their subjects in writing an essay for the EAP writing course. The students also pointed out that much of the topics they were given did not require them to do research or consult sources as they were based on personal or general topics.

\section{3 research question 3: What tutors consider to be good academic writing?}

\subsubsection{Shared views on what is valued in academic writing}

Because I was interested in finding out whether there were any differences in what EAP tutors and content lecturers value in students' writing, I asked the participants to explain what they considered to be good writing.

The EAP tutors shared the same perception of what they would want the students to be doing. The tutors emphasised structure and organization of ideas and language as very important in students' writing. According to one tutor, there should be evidence of "organisation of their (students') thoughts, organisation in the sense of cohesion between one idea and the next. One tutor talked of "appropriateness in terms of accuracy in the use of tenses, in the use of punctuation, spelling" and another mentioned "how students develop their paragraph, how they are able to organise their ideas in a coherent fashion". They also mentioned that they valued more 'good expression and clarity'.

On the other hand, content lecturers also shared the same perception of what is important in good essay writing. I found out that "originality", "creativity", "synthesis of ideas", "not reproducing what was taught in class", "not cutting and pasting" but showing understanding of concepts" were crucial to students" writing success.

One tutor defined creativity as the ability to "combine own ideas together with ideas from the sources" This indicates that the process of producing academic texts cannot be completely original; writers depend on what already exist to produce text. In the same way another tutor views creativity as "build(ing) from whatever other people have found out". Her opinion is that "...you cannot just write an essay without consulting sources, but can you stand there and argue a point...can I hear that this is a person who has got their own point of view".

\section{Discussion of the findings and pedagogical implications for the teaching of the EAP writing course}

The limitations of this study need to be considered when discussing these findings. Firstly, this study examined the types of written assignments and tasks that students produce in the two writing contexts in only one University. The same departments in different universities might offer different courses which might require different writing requirements. Secondly the findings of this study are based on data collected through interviews with tutors and students from these departments and a limited sample of assignments. I did not collect samples of handouts and course outlines and syllabi for the different courses. I believe an examination of these documents would have provided more information on the nature and types of written assignments and types of genres students write in these departments. The findings reported are based on tutor and students' views of writing in their departments and the limited sample of assignments collected.

In spite of the limitations mentioned above, I believe that this study provides useful starting point to look beyond the traditional essay to examine writing tasks and genres that students are expected to perform in university content courses. The study identified writing assignments required in undergraduate Media Studies and the type of writing students are taught in the EAP writing course. This study indicated that written assignments at the University cover both the traditional academic essay and a variety of genres that are specific to the discipline. Womack (1993) and Andrews (2003) recognize the essay as the 'default genre' for students' writing in higher education and is "privileged by the assessment system" (Womack 1993:42). The influence of the essay is felt by students because "it naturally forms, for students, the central action of the course- what they learn is more powerfully determined by what they write than what we teach (tutors)" (Womack 1993: 42).

Tutor comments from Media Studies indicated that essay writing was done primarily to assess students' understanding of what they have learnt. This seems to be perceived as such over a wide variety of contexts. Research 
in the UK context, for instance, indicates that essay writing was central to assessment in higher education (Andrews 2003). Students' success in a course is determined by what they write, which will in turn reflect how much they have learnt. Neumann et al. (2002) argue that in the applied disciplines, tutors attach importance to "knowledge application and integration" (p.408) students have to show "understanding of complex qualitative domain" (p. 409), and this is assessed mainly in the form of essay writing. Ivanic and Simpson (1992) argue that the student does not have the responsibility of an expert writer which is to inform the readers, "but has to perform a certain writing task in order to be assessed" (p.146). Creme (2000) also argues that it is "the tutor, as the representative of the discipline who has the power to make decisions about what goes into student writing and what stays out (p.102).

There was considerable consistency on what is valued in essay writing among tutors. Although EAP tutors emphasized language, issues of structure and organization and development of ideas, it is interesting to note that they shared the same views with lecturers in Media in that they valued the same qualities in students' writing. This is corroborated by what Nesi and Gardner's (2006) finding that tutors in different disciplines valued many of the same qualities in students' writing. Originality or creativity and synthesis of ideas from other sources are qualities tutors valued most in students' essay writing. This supports Nesi and Gardner's (2006), and Woodward-Kron's (2004) findings that tutors highly valued originality or creativity and synthesis of ideas. North (2005) also indicates 'syntheses as a characteristic of the soft disciplines'.

A survey of writing tasks that students are expected to write in their target contexts indicated a wide range of disciplinary genres that students have to do which reflect the "conventions and purposes of workplace texts"( Nesiand Gardner 2006). Zhu (2004a) also found out that while some genres were common to the wider university context, others were more specific to the business discipline he was researching on. Hyland (2002:389) also argues that the "the discourses of the academy do not form an undifferentiated, unitary mass but a variety of subject-specific literacies".

Such a range of writing creates a challenge for both the EAP tutor who is tasked with giving students support for writing in the disciplines and the students who have to master all these types of writing. Stierer argues that 'it is hardly surprising that some students find it difficult to build up a sense of confidence and progression in their ability to write academically as they move from one assignment to the next, and from one module to the next" (Stierer 2000:186). However some of the students interviewed indicated that what they learnt from the EAP course has helped them.

There are several implications for teaching essay writing that arise from the findings discussed above. The findings underline the fact that pedagogic disciplinary genres are not homogenous and that there are considerable variations in terms of genres that students have to produce. The findings also point to the fact that academic writing tasks are highly situated within the disciplines and "what are perceived to be appropriate conventions vary...depending on the specific contexts and role students are expected to assume" (Zhu 2004:44-45a). The findings reveal that even at the level of the 'default genre', that is the essay; there are variations in requirements and expectations within the two departments. This highlights the need to adopt a discipline-oriented and contextualized approach to teaching the academic essay even within an EAP context (Hyland 2002c). Students need to be made aware of the disciplinary preferences in their EAP writing course. The teaching of the academic essay should be in line with the norms and conventions of the discourse communities.

The idea of specificity (which is the title of this article) challenges the view that students writing problems are common across the disciplines and that there are generic skills which can apply in whatever learning environment students are in. Central to these debates is the extent to which EAP writing course prepares students for writing in their disciplines and to what extent EAP writing teachers should socialize students into disciplinary writing practices. Zhu (2004a) warns us that we need to consider carefully what constitute specificity and what the specific role of the EAP tutor would be as the EAP tutor is not a member of the disciplinary communities and is not an expert. But the question is how do we take into account the 'discipline-specificity' we are talking about in an EAP programme which is intended to assist not just one discipline but a number of disciplines at the same time (Bhatia 2002)?

This research has attempted to unpack some of the degrees of specificity we might consider in teaching. For instance, it has served to inform us of what is happening in the Departments of Media Studies in terms of what is valued by tutors, understanding the nature of writing tasks and genres that students are required to produce in their target contexts and in terms of discourse conventions that tutors value in this department. These could be the starting point for teaching discipline specific writing in the EAP course.

Ideally attaining specificity could be achieved by collaboration with content tutors. Students could also be given the opportunity "to conduct their own explorations of the discourse they hope to gain control of" (Hirvela 1997:83) within 
an EAP writing course. Zhu (2004:44a) argues that EAP tutors could act as "facilitators and perhaps co-investigators of discursive practices within the target communities" and therefore would not be required to have expert knowledge of the target communities.

Another major implication of the study is in identifying whether there is a gap between the EAP pedagogic goals and the expected practices and values in the departments. The results seem to suggest some potential discrepancies between skills required for writing in the departments of Media Studies and Primary Education and those taught in the EAP writing course. For instance, although both EAP and content tutors seemed to hold similar views about what they value in students' writing, EAP tutors seemed to put greater emphasis in teaching general principles of writing that are transferable such as structure and organization, i.e. paragraphing and development of ideas, fluency of expression of ideas, consistency in making an argument, ability to communicate ideas clearly and citation skills. Therefore topics that tutors give to students are used as a springboard for practicing these skills. The EAP writing assignments also often emphasize short essays which tend to be based on personal issues. However, Johns (1988:706) warns that "employing artificially constructed topics and materials, is insufficient for students who are exposed daily to the linguistic and cultural demands of authentic university classes". Content tutors also seem to place more emphasis over and above the generic skills on the content and that the students' writing should reflect the discourse practices, values and beliefs of the departments.

\section{Conclusion}

The study identifies a variety of written assignments that are done in the Departments of Media Studies. The picture that emerges is consistent with the body of research suggesting that students' writing at the university is shaped by the disciplines (North 2000) and that writing skills may be context specific.

The study also acknowledges the difficulties EAP tutors have teaching students from different disciplines. One interesting view held by EAP tutors in this study was that students' writing problems were common across departments and that the help they gave to students was mainly in the form of 'generic skills' which could be transferred across contexts. This view was also held by members of the Media Studies in this study. However, the tutors in all the two departments seemed to differ on how they perceived students' writing needs. The EAP tutors take the view that it is all about issues of language, structure and genre knowledge while tutors in the two content departments indicate that some issues on essay writing are about the discourse community knowledge and expectations. This has implications for students because often tutors see students' writing problems as learners' own weaknesses rather than lack of knowledge on what is expected from them by their tutors.

The question is how can the EAP course bridge the gap between writing in the departments and writing in the EAP course? The answer could possibly lie in the fact that since the goal of an EAP writing course is learning transfer, the course should go beyond teaching generic skills to teach communication skills that are appropriate to understanding writing in disciplinary departments. As Carter (2007) argues, we need to understand that what counts as good writing is writing that meets the requirements and expectations of content tutors. North (2005:531) also suggests that in order to socialize students into the discourse of their faculties we need to "disentangle precisely which aspects of writing are generalizable and which are discipline specific".

It is through research like this that we can gain better understanding of writing in content course. It is therefore my hope that these findings will help to bridge the gap between teaching the general academic essay and addressing the specific needs of students in their different departments within the University of Botswana context.

\section{References}

Andrews, R. (2003). The end of the essay? Teaching in Higher Education, 8(1), 117-127. http://dx.doi.org/10.1080/1356251032000052366

Baynham, M. (2000). Academic writing in new and emergent discipline areas. In M. R. Lea \& B. Stierer (eds.) Student Writing in Higher Education: New Contexts (pp.17-31). Buckingham: SRHE and Open University Press.

Berkenkotter, C., Huckin, T.N. and Ackerman, J. (1991). Social context and socially constructed texts: The initiation of a graduate student into a writing research community. In C. Bazerman\& J. Paradis (eds.) Textual dynamics of the professions (pp. 191-215). Madison, WI: University of Wisconsin Press.

Bhatia, V. K. (2002). A generic view of academic discourse. In J. Flowerdew (ed.) Academic discourse (pp. 21-39). England: Longman.

Braine, G. (1989). Writing in science and technology: An analysis of assignments from ten undergraduate courses. English for Specific Purposes, 8, (1) 3-15. http://dx.doi.org/10.1016/0889-4906(89)90003-3 
Braine, G. (1995). Writing in the natural sciences and engineering. In D. Belcher and G. Braine (eds.) Academic writing in second language: Essays on research and pedagogy (pp. 113-134). Norwood, NJ: Ablex Publishing Corporation.

Carter, M. (2007) Ways of knowing, doing, and writing in the disciplines. College Composition and Communication, 58 (3), 385-418. [Online] Available: http://www.jstor.org/stable/10.2307/20456952

Crème, P. (2000). The personal in university writing: Uses of reflective learning journals. In M. R. Lea \& B. Stierer (eds.) Student Writing in Higher Education: New Contexts (pp. 97-111) Buckingham: SRHE and Open University Press.

Dornyei, Z. (2007). Research methods in applied linguistics. Oxford: Oxford University Press.

Gimenez, J. (2008). Beyond the academic essay: Discipline-specific writing in nursing and midwifery. Journal of English for Academic Purposes, 7, 151-164. http://dx.doi.org/10.1016/j.jeap.2008.03.005

Hirvela, A. (1997). Disciplinary portfolios' and EAP writing instruction. English for Specific Purposes, 16 (2), 83-100. http://dx.doi.org/10.1016/S0889-4906(96)00037-3

Hyland, K. (2002c). Specificity revisited: How far should we go now?. English for Specific Purposes, 21(4), 385-395. http://dx.doi.org/10.1016/S0889-4906(01)00028-X

Hyland, K (2005a). Metadiscourse. London: Continuum.

Hyland, K. (2008b). Genre and academic writing in the disciplines. Language Teaching, 41 (4), 543-562. http://dx.doi.org/10.1017/S0261444808005235

Ivanic, R. and Simpson, J. (1992). Who's who in academic writing?. In N. Fairclough (ed.) Critical Language Awareness (pp141-171). London: Longman.

Leki, I. \& Carson, J. (1994). Students' perceptions of EAP writing instruction and writing needs across the disciplines. TESOL Quarterly 28 (1), 81-101. http://dx.doi.org/10.2307/3587199

Leki, I. and Carson, J. (1997). Completely different worlds': EAP and the writing experiences of ESL students in university courses. TESOL Quarterly 31 (1), 39-69. http://dx.doi.org/10.2307/3587974

Nesi, H. \& Gardner, S. (2006). Variation in disciplinary culture: university tutors' views on assessed writing tasks (pp. 1-19). Unpublished paper, CELTE, University of Warwick. [Online] Available: http://www2.warwick.ac.uk/fac/soc/al/research/collect/bawe/papers/variation_in_disciplinary_culture.pdf.

Neumann, R., Parry, S and Becher, T (2002). Teaching and learning in their disciplinary contexts: A conceptual analysis. Studies in Higher Education, 27(4) 405-417. http://dx.doi.org/10.1080/0307507022000011525

North, S. (2005). different values, different skills? A comparison of essay writing by students from arts and science background. Studies in Higher Education, 30(5), 517-533. http://dx.doi.org/10.1080/03075070500249153

Samraj, B. (2004). Discourse features of the student-produced academic research paper: Variations across disciplinary courses. Journal of English for Academic Purposes, 3 (1), 5-22. http://dx.doi.org/10.1016/S1475-1585(03)00053-5

Stierer, B. (2000). Schoolteachers as students: Academic literacy and the construction of professional knowledge within masters courses in education'. In M. R. Lea \& B. Stierer (eds) Student Writing in Higher Education: New Contexts (pp. 179-195). Buckingham: SRHE and Open University Press.

Womack, P. (1993). What are essays for?' English in Education, 27 (2), 42-59. http://dx.doi.org/10.1111/j.1754-8845.1993.tb01101.x

Woodward-Kron, R. (2004). Discourse communities' and 'writing apprenticeship: An investigation of these concepts in undergraduate education students' writing'. Journal of English for academic Purposes, 3 (2), 139-161. http://dx.doi.org/10.1016/j.jeap.2003.09.001

Zhu, W. (2004a). Faculty views on the importance of writing, the nature of academic writing, and teaching and responding to writing in the disciplines. Journal of second language Writing, 13 (1), 24-48. http://dx.doi.org/10.1016/j.jslw.2004.04.004

Zhu, W. (2004b). Writing in business courses: An analysis of assignment types, their characteristics and required skills. English for Specific purposes, 23 (2), 111-135. http://dx.doi.org/10.1016/S0889-4906(02)00046-7 


\section{Appendix A: interview guide}

\section{For content tutors}

1. Can you tell me what types of written assignments you set for your students?

2. In what ways do the various types of assignments you mentioned above differ?

3. Do the writing tasks differ according to year of study?

4. What do you value most in students' written work?

5. In your opinion what are the main qualities of a good piece of written work?

6. What makes a good argumentative essay?

\section{Interview Guide- EAP tutors}

1. What role does assignment writing play in your department?

2. Can you tell me what types of written assignments you set for your students?

3. In what ways do the various types of assignments you mentioned above differ?

4. Can you give me examples of types of essay prompts you give students?

5. What do you value most in students' written work?

6. In your opinion what are the main qualities of a good piece of written work?

\section{Interview Guide- Students}

1. Tell me about the kind of writing you do in the EAP class?

- What types of essay topics do you write in the EAP class?

- Who chooses the topics for you?

2. Do you find writing for EAP class similar or different from writing in your Media studies class?

In what ways is it different?

In what ways is it similar?

3. What do you think the EAP tutors are looking for when they mark your written assignments?

○ Do they put emphasis on content or language?

4. What do you think the Media studies tutors are looking for when they mark your written assignments?

5 . Does writing in your EAP class help you in writing in the media class? 